\title{
COPYRIGHT ISSUES IN CREATING DIGITAL ARCHIVES
}

\author{
by
}

Laura N. Gasaway

\begin{abstract}
As digital archives continue to increase, libraries must face concerns relating to copyright, and find workable, legal solutions to these issues. This article describes three types of digital library projects. Public domain material and its accompanying copyright implications are first described. These include works on which copyright has expired; materials of unclaimed copyright and the current restraints; and works produced by the federal government. Second is a discussion on fair use of copyrighted works. Third, issues surrounding uncertain copyright status are explored. License agreements, particularly in relation to interlibrary loans, and cooperative projects wherein agreements are reached between owner and library so that no copyright problems exist, are also covered. The author concludes that while the creation of digital libraries brings copyright problems with it, these are not insurmountable and explains why.
\end{abstract}

\section{INTRODUCTION}

Libraries are increasingly interested in creating and using digital archives. The rapid development of scanning technology has brought this interest to the forefront, and indeed a variety of projects are underway to develop and share archives of digital works.

Libraries have a number of reasons for being interested in digital archives: (1) to preserve fragile material, (2) to increase the ability to search a variety of materials, (3) to make unique materials widely available, (4) to gain access to materials not held in a local collection, (5) to save space, (6) to develop unique products to market, and (7) even to save trees by reducing the need to rely on paper copies of works. Additionally, a library might have a combination of these reasons.

Because creating a digital archive is a reproduction of a work, libraries must address copyright concerns. In some situations, the copyright issues may be nonexistent; in others, problems may be easily solved by agreements with the copyright owner. There may also be situations when the copyright issues are so serious that the digital archive project must be abandoned.

\section{DIGITAL LIBRARY PROJECTS}

Current digital library projects are of three types. First, there are many projects being created from public domain material. Second, libraries are creating digital archives of copyrighted works. Third, there are cooperative projects between the copyright owner and a library or other entity. The copyright concerns and potential solutions differ depending on the type of material and the project.

\section{Public Domain Material}

Digital library projects of materials in the public domain are the easiest since there are no serious copyright problems. Everyone owns material in the public domain and anyone may freely reproduce the works. There is no exclusivity of rights and no need to seek permission from anyone. Materials available in the public domain are very important for scholars and researchers as well as to libraries. Making this material available digitally is equally important. Just because it is copyright-free does not mean that the works are freely available, however. For years researchers have traveled to distant libraries and archival collections to use public domain material that exists only in one or very few copies. Creating digital copies of these works that will be widely available on the World Wide Web is a tremendous service that a library can perform for scholarship and research.

There are three types of materials that are in the public domain. First, all the works on which the copyright has expired are in the public domain. This is the largest group of materials. While the term of copyright has varied over the years, there is still a certain time when copyrighted works pass into the public domain. For a chart that details when works pass into the public domain in the United States, see http://www.unc.edu/ unclng/public-d.htm.

The second type of materials in public domain work are those in which the author never claimed copyright or which were dedicated to the public by publishing without notice under the 1909 Copyright Act. Some authors choose not to claim copyright and include a statement with their works to the effect that " The author makes no claim of copyright; you are free to reproduce this work for any purposes." Under the previous U.S. Copyright 
Act, the 1909 statute, if the author or publisher published a work and failed to include a notice of copyright (i.e., the () or the word "copyright," the name of the copyright holder, and the year of first publication), he or she lost the rights to the work. In other words, it was a fatal flaw. This did not continue to be the case under the 1976 Copyright Act. For works published after January 1,1978 , the author had five years to correct any accidental omission of notice by going back and putting the notice on unsold copies. When the U.S. joined the Berne Convention in 1988, notice became optional on the part of the copyright holder. So, there will be no additional works passing into the public domain for failure to include copyright notice.

The third type of work in the public domain is works produced by the federal government. Section 105 of the Copyright Act of 1976 states that works produced by the federal government or its employees acting within the scope of their employment are not eligible for copyright protection. This is not true of state or local government works, however. Since this is a federal statute, only federal government works are denied eligibility for copyright protection.

\section{Copyrighted Works}

In order to digitize a work that is copyrighted and make it available, permission must be sought and royalties paid if the copyright owner so requests. Works in this category are not the most difficult with which to deal. In fact, it is fairly clear what must occur. Section 106 of the Copyright Act gives copyright owners five exclusive rights: reproduction, distribution, adaptation, performance, and display. While there are limitations on the owner's exclusive rights, only fair use merits consideration.

Are digital archives of copyrighted works fair use? Probably not. Section 107 of the Act states:

The fair use of a copyrighted work, including such use by reproduction in copies for purposes such as criticism, comment, news reporting, teaching (including multiple copies for classroom use), scholarship, or research, is not an infringement of copyright.

A court will consider 4 factors in determining whether use of a copyrighted work is a fair use: (a) purpose and character of the use, (b) nature of the copyrighted work, (c) amount and substantiality used, and (d) market effect. Purpose and character of the use favors scholarly and nonprofit educational and research uses. Since a digital archive is of necessity made generally available, then the equivalent of multiple copies is made through each user of the work. Fair use typically does not favor multiple copying.

The nature of the copyrighted work factor examines the work itself. Is it a novel? A musical score? A short news note? Often libraries want to digitize out-of-print works. While the fact that the work is no longer in print is one consideration, it does not mean that the work may be freely reproduced. Out-of-print and out-of-copyright are not the same thing. The third factor, amount and substantiality, looks at the quantity of the work reproduced. Further, there is a qualitative aspect to this factor, and if "the heart of a work" is reproduced, then it is too much, regardless of the quantity copied. Market effectexamines the effect on the potential market for, or value of, the work. Many of these works have little market value, but courts appear to consider any market that the copyright holder might develop, and this would include the digital market.

If the work is digitized by a library but is not made available to users, then perhaps permission of the copyright holder is not required. But why else would a library create a digital archive except to make it available to users, and typically to users throughout the world? Thus, digitizing copyrighted works most certainly will require permission from the copyright holder to avoid liability for infringement.

\section{Copyright Status Uncertain}

The copyright status of many works a library may want to digitize may be uncertain. For example, it is much more difficult to determine the status of works published abroad than it is for works published in the United States. Additionally, what about all the unpublished works that existed in archival collections all over this country? The copyright status of this second type of work will become clarified over the next few years.

Works that existed as of January 1, 1978, but which have never been published, will pass into the public domain at the end of 2002 or life of the author plus 50 years, whichever is greater. This will encourage libraries to digitize those works since they will definitely be copyright free. If an unpublished work existed January 1,1978 , but which is published before the end of 2002, the work will pass into the public domain at the end of 2027 or life of the author plus 50 years, whichever is greater. Thus, the status of a huge amount of archival material will become clear, and, in fact, such works will become public domain over the next few years.

There will still be other works for which the status is unclear for a variety of reasons. Libraries that wish to create digital archives of these works should try to determine the copyright status as best they can. At some point, however, the library (working with legal counsel) may determine that it is willing to assume the risk involved in potential infringement and will go forward with the digital project.

\section{Cooperative Projects}

There are certainly projects where the copyright holder and the library have agreed that the library will createdigital copies of the owner's works. Thus, the copyright problems are nonexistent because the library and the owner have reached an agreement about the project. Often these projects are for older material, back runs of journals, etc., and the agreementbenefits both parties in addition to potential users of the digital library. 


\section{ACQUIRING (ACCESSING) DIGITAL ARCHIVES}

In addition to creating digital archives, libraries want to access digital materials made available by other libraries and companies. Sometimes that access is free and there is no license agreement involved. Often, however, the library must sign a license agreement and pay a license fee to obtain access.

Section 108(f)(4) of the Copyright Act of 1976 states: "Nothing in this section in any way affects any contractual obligations assumed at any time by a library when it obtained a copy of a work in its collection." In other words, libraries are bound by any license agreements they execute. Thus, the library should ensure that the agreement contains the provisions that facilitate the anticipated use. Issues that should be addressed include interlibrary loan and what happens when the license is terminated. To satisfy interlibrary loan requests, the library needs a clear provision about whether it may use the digital archive for which it has a license. If the license states that use is restricted to the institution, then interlibrary lending is not permitted. When the license expires or is terminated by either party, the library may want to negotiate up front as to whether it gets to retain the digital archive as it existed at the time of termination. A further agreement term might be that, after expiration of the license, not only does the licensee get to retain the archive as it existed at the time of termination, but that the licensee be permitted to upgrade the archive to new platforms over time.

\section{COPYRIGHT IN WORKS YOU DIGITIZE}

Most digital library projects deal with works in the public domain, manuscripts, incunabula, etc. Creating a digital version of the work does not change the underlying copyright status of the work. Is the act of digitizing itself enough to create a new copyright?
Some argue that the digital version creates a new copyright, but most copyright experts disagree. If the underlying photograph, literary work, etc. is in the public domain, then so is the digital version. The digital version is merely a copy in electronic form. Certainly, if there were sufficient originality in the digital work then it would be eligible for copyright protection, probably as a derivative work. If the library has added descriptive material, comment, criticism, etc., then perhaps there is enough new material to qualify for copyright. But it is only the new material that is protected. However, the library might seek copyright protection for the collection.

Existing rights are probably best controlled through a license agreement. The library itself may want to develop a license that users would have to sign to obtain access to the archives. A license agreement can be used even if there is no charge for access to the material. Terms could include how to cite the work, giving credit to the library that has created the archives, etc.

\section{CONCLUSION}

Creating digital libraries is an important development in the history of scholarship and research. Scholars everywhere hope that libraries will continue to develop digital archives that facilitate their research. While there are copyright problems, they are not insurmountable, and libraries should continue to work with publishers on agreements when they are needed and certainly to produce digital archives of public domain material.

Laura N. Gasaway is Professor of Law and Director of the Law Library at the University of North Carolina. She teaches courses in Intellectual Property and Cyberspace Law as well as on Law Librarianship and Legal Resources. She has written widely on both copyright and law management issues and is a frequent speaker on these topics.

Phone: (919) 962-1049;

E-mail: LAURA_GASAWAY@UNC.EDU 